Proceeding Paper

\title{
P.A.S.T. in Coast Project: A Tool for the Research and Enhancement of Prehistoric Archaeology on the Amalfi Coast ${ }^{\dagger}$
}

\author{
Luca Di Bianco $^{1}\left(\mathbb{D}\right.$, Claude Albore Livadie $^{2}$ (D) and Saverio G. Malatesta $^{3, *(\mathbb{D})}$ \\ 1 Centro Europeo per i Beni Culturali, 84010 Ravello, Italy; ldb.dibianco@gmail.com \\ 2 Centre Camille Jullian UMR 1299 AMU-CNRS, 13097 Aix-en-Provence, France; alborelivadie@gmail.com \\ 3 Interdipartimental Research Center Digilab, Sapienza Università di Roma, 00185 Roma, Italy \\ * Correspondence: saveriogiulio.malatesta@uniroma1.it \\ + Presented at the ArcheoFOSS XIII Workshop-Open Software, Hardware, Processes, Data and Formats in \\ Archaeological Research, Padova, Italy, 20-22 February 2019.
}

\begin{abstract}
The archaeological complex of the Amalfi Coast represents a sector of great development capacity within an area defined as a UNESCO World Heritage site on the basis of the typical stratified cultural landscape. The project presented in this report acts in a specific field of archaeology, prehistoric and protohistoric, of which there are many examples in the Amalfi Coast, even if they are not always clearly legible, and focuses on the analysis of old data, on the acquisition of new information and on their processing through an open-source GIS database. The project seeks results on two different levels: the purely scientific and the more sociocultural.
\end{abstract}

Keywords: prehistory; archaeological research; database; GIS; open-source

Citation: Bianco, L.D.; Livadie, C.A.;

Malatesta, S.G. P.A.S.T. in Coast

Project: A Tool for the Research and

Enhancement of Prehistoric

Archaeology on the Amalfi Coast.

Environ. Sci. Proc. 2021, 10, 3.

https://doi.org/10.3390/

environsciproc2021010003

Academic Editors: Sara Gonizzi Barsanti, Saverio Giulio Malatesta and Augusto Palombini

Published: 13 October 2021

Publisher's Note: MDPI stays neutral with regard to jurisdictional claims in published maps and institutional affiliations.

Copyright: (c) 2021 by the authors. Licensee MDPI, Basel, Switzerland. This article is an open access article distributed under the terms and conditions of the Creative Commons Attribution (CC BY) license (https:// creativecommons.org/licenses/by/ $4.0 /)$.

\section{Introduction}

P.A.S.T. in Coast-Pre-protohistoric Archaeological Studies through new Technologies on the Amalfi Coast-is a research project in progress, in the Lattari-Amalfi Coast area, which has as its objective a prehistoric and protohistoric archaeology, understood in its various aspects of research, use and enhancement; research, conducted with the aid of new technologies; use of the local cultural heritage, especially that which is not very "visible" and underestimated, to increase the opportunities for understanding and sharing; and enhancement of history and the territory, which aims to raise public awareness of little-known issues, while providing digital solutions to support involvement and a real knowledge of the place.

The desire to propose a project focused on prehistoric and protohistoric archaeology stems from the assessment of the lack of modern and systematic study approaches to the subject in the area. In fact, if on the one hand the history of studies of the period in question demonstrates the existence of various and rich archaeological contexts, such as the well-known Palaeolithic sites of Grotta La Porta and Grotta del Mezzogiorno di Positano [1], on the other it is necessary to underline the partial, casual and distant nature of the research carried out.

The complexity of this territory, with its homogeneous and exceptional natural and geo-environmental characteristics, which contains numerous archaeological testimonies, often not very visible, required, alongside the use of traditional analysis methods such as surface reconnaissance, archival research, and study of materials, the use of an open-source GIS platform, to collect all the historical-archaeological and spatial information available in a database. The use of this tool offers, among other things, the possibility of extending the archaeological analysis of the territory to different periods of human history.

The project, sponsored by the Superintendence of Archaeology, Fine Arts and Landscape for the provinces of Salerno and Avellino, makes use of the collaboration of the 
European University Centre for Cultural Heritage of Ravello and Archeo and Arte3D Lab of the DigiLab Interdepartmental Research Centre-Sapienza University of Rome.

\section{Project Status}

The bibliographic and archival research has allowed the recovery of all published and unpublished data relating to the pre-protohistoric archaeological finds of the area; the analysis of finds from excavations of prehistoric sites preserved in various museums and institutes throughout the country (for example, a deposit in the Department of Sciences of Antiquity and Archaeology of the University of Pisa; a deposit in the L. Pigorini section of the Museum of Prehistory of the Civilizations of Rome; the Museum I. Cerio of Capri; the Provincial Archaeological Museum of Salerno; the Museum of Ethno-Prehistory of the CAI of Naples) has allowed us to update dated information. A superficial prospecting campaign has been carried out in the territory of the Lattari Mountains, during which a new protohistoric site has been identified, located in the internal territory of the Amalfi Coast [2].

A geographic information system was also developed using open-source software and methodologies. Preliminary to the creation of the GIS, a database was designed, capable of collecting all the data deriving from the research activity previously described, in a structure that allows not only a list of the cases, but also the potential to generate new possibilities of analysis correlating the information thus generated.

The development of a specific complex and structured database responding to the needs of prehistoric studies, partly different from those of other chronological and cultural areas such as classical or medieval, carried out by the SH.AR.P.P. (Shared Archaeological Platform for Prehistory, in this volume), has found its practical application in this context. In this database, the various items allow the registration of personal and administrative data; geographical and geological, related to any places of interest, as regards the exploitation of the environment by man. These include deposits of raw material in the vicinity or the presence of springs, regardless of evidence of actual exploitation; bibliographic aspects, with all the necessary references to the literature and an eye to the publications available online at various levels of opening; aspects related to research activities, which include people and organizations involved in them, the times and methods of research, and the progress of specialist studies; and those purely archaeological, related to specific chronocultural characters.

The aim of the system is the desire to overcome the "archaeological map" approach, in which there is a simple visualization of the existing sites and their characteristics in graphic form, to create instead an integrated system of archaeological and geographical data that interact with each other and that generate new ones. Another purpose is to make such a system accessible to every category of user: to the curious who wants to deepen their historical understanding of their own territory or of others; to the student who needs to collect further data and bibliography; to the researcher who intends to address issues that involve considering the relationship between man and the environment or to recognize patterns within his research; to the professor who wants to establish relationships with others interested in the same topics; to those who wish to undertake enhancement actions by enhancing an aspect hitherto neglected in the panorama of the territorial cultural and tourist sites, to initiate further enhancement project possibilities, focusing on technologies in their aspect of immediate tools for involvement and dissemination.

This has led to the creation of an open Web-GIS platform that welcomes archaeological and territorial data within a descriptive system specifically structured for prehistoric and protohistoric archaeology, but which does not exclude data relating to other contexts (Figure 1). Finally, the creation of the web part of PAST in COAST was started, creating the digital structure that houses the GIS, which can be consulted at the link www.past-project. eu (accessed on 12 May 2020). 


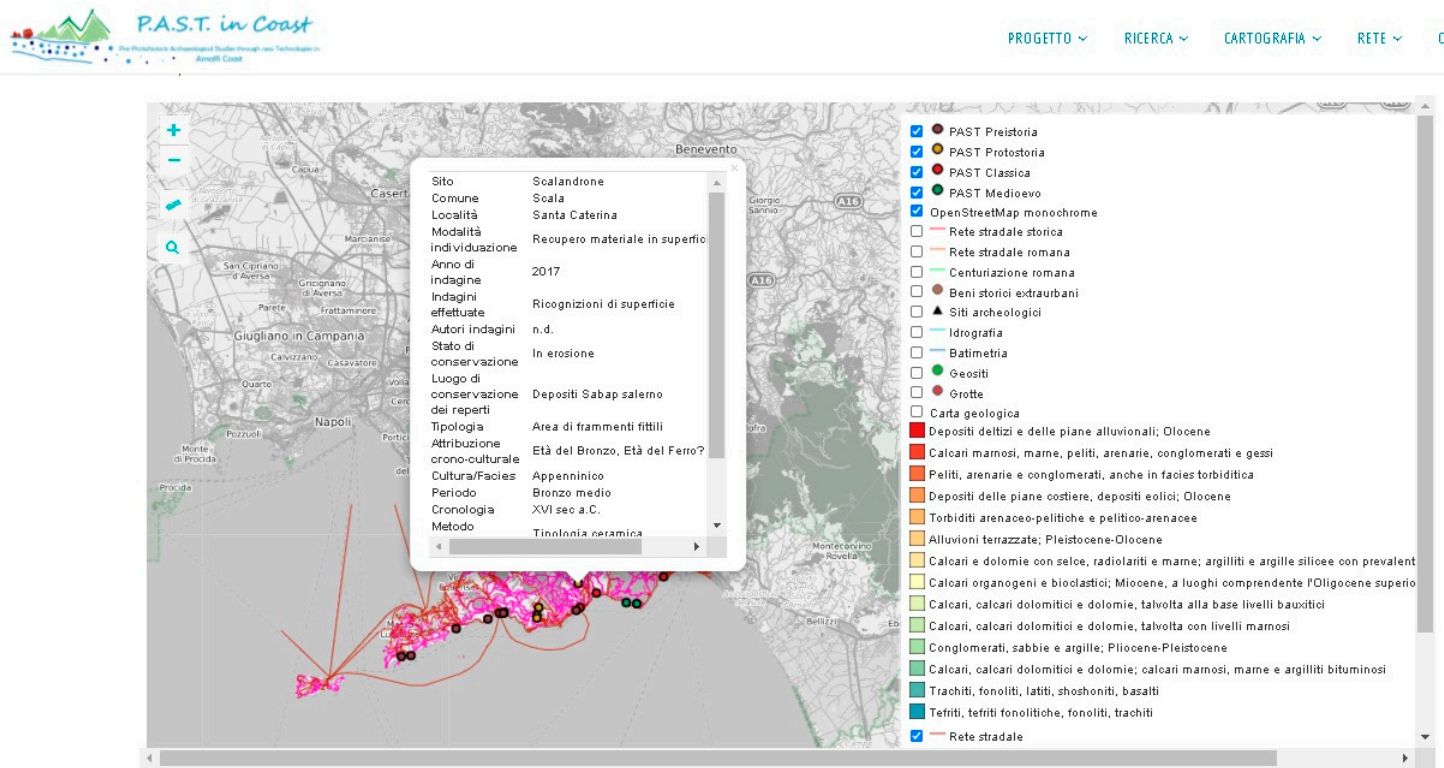

Figure 1. Example of a site-sheet view of the PAST in Coast GIS.

\section{Perspective}

The themes mentioned at the opening, of research, enhancement and use of the Prehistoric Archaeological Heritage of the Amalfi Coast, represent the path to follow for the complete implementation of the PAST in Coast project.

Starting from the research, it will be possible to obtain a complete enhancement of the prehistoric archaeological heritage of the Lattari Mountains-Amalfi Coast, capable of combining correct communication of knowledge of the prehistory of the area and the effective use of the related contexts/sites, mostly located in a mountain environment and characterized by low attractiveness, as they are hidden in the landscape (Figure 2).

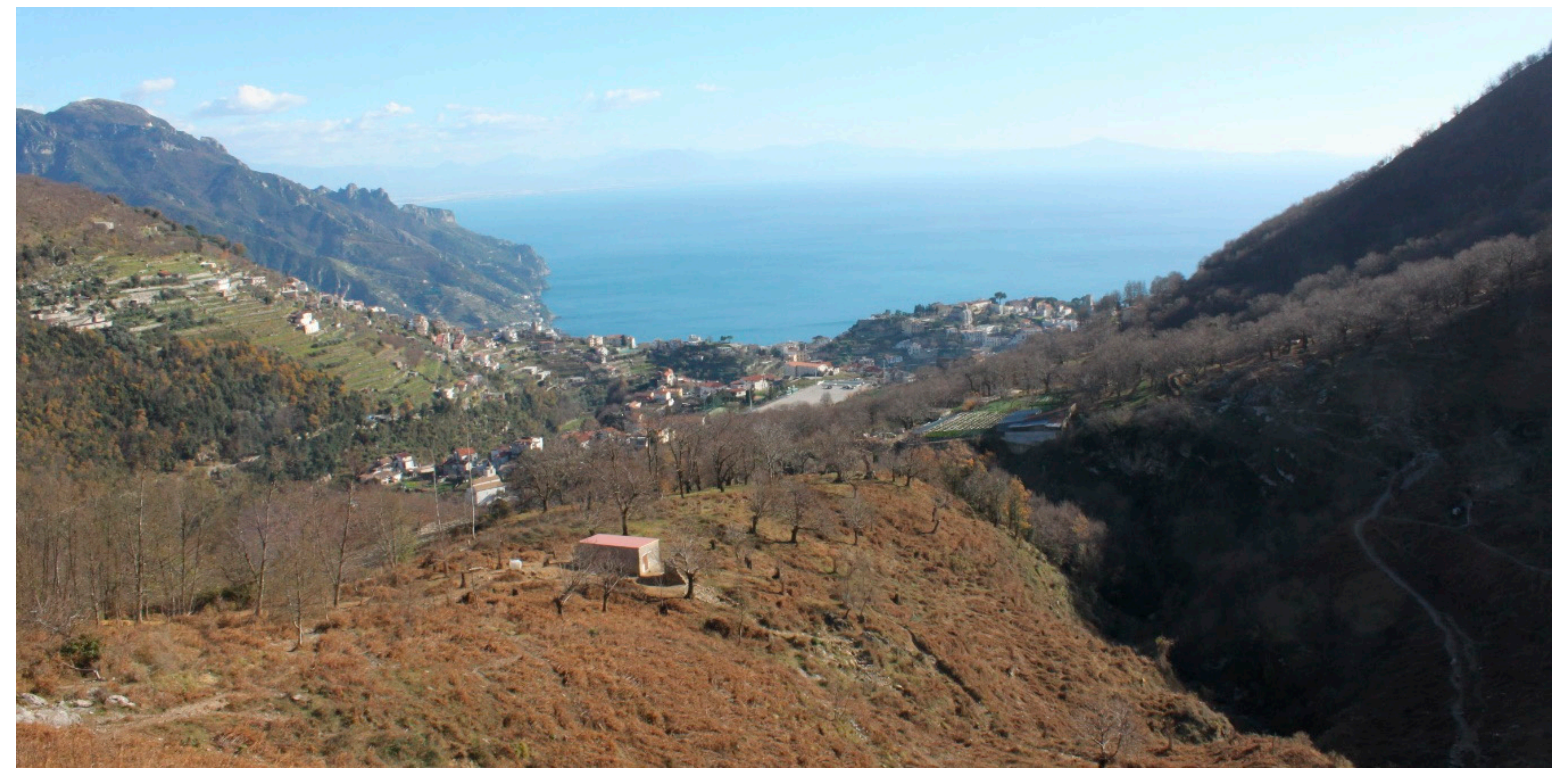

Figure 2. The pre-protohistoric sites of the Amalfi Coast are hidden in the landscape: a Bronze Age site has been identified on the plateau in the foreground.

The aim is to achieve a positive impact both on a purely scientific level and on a socio-cultural and local economic level [3]. 
The ideal path to start foresees, therefore, a unitary and integrated management of the whole of the archaeological heritage, of the naturalistic one and of the services connected to them, recalling a concept of a "cultural system of the territory itself", a purpose that requires for its implementation a joint and coordinated work over time and whose management can only be implemented through the use of a GIS system, within which multiple data sources can be interoperated, with a view to relational systems and LODs, while also preparing query tools to be remote, via API, and with the release of open data. The project presented here is intended as a "pilot" from this point of view. Operating in the field of prehistoric and protohistoric archaeology, of which rich testimonies are preserved on the Amalfi Coast that are not always clearly legible, it is proposed to achieve a positive impact both on a purely scientific level and on the socio-cultural and local economic level, in such a way that the development potential of this sector on a wider territorial scale needs to be assessed.

Institutional Review Board Statement: Not applicable.

Informed Consent Statement: Informed consent was obtained from all subjects involved in the study.

Conflicts of Interest: The authors declare no conflict of interest.

\section{References}

1. Martini, F. (Ed.) L'Epigravettiano tra 15000 e 10,000 anni da oggi nel basso versante tirrenico; casi studio dell'area calabro-campana. In L'Italia tra 15000 e 10,000 anni fa. Cosmopolitismo e Regionalità nel Tardoglaciale; Atti della tavola rotonda: Firenze, Italy, 2007; pp. 157-207.

2. Di Bianco, L.; Albore Livadie, C.; Malatesta, G.S. Il Progetto “P.A.S.T. in Coast” e l'insediamento protostorico dello Scalandrone di Scala (Costa d'Amalfi-Campania). Territ. della Cult. 2017, 27, 22-29.

3. Malatesta, S.G.; Milella, M. WikiLoves Monuments e archeologia: Condividere la conoscenza. Archeologia e Calcolatori 2013, 4, 53-59. 